authors said. They detected the new deletion - which, with 12,000 base pairs, accounts for about $15 \%$ of the gene - using a technique patented by the Pasteur Institute called combed DNA colour bar coding.

William Hockett, a spokesman for Myriad, says that the company is developing a method to detect such large deletions and that a commercial test will be available by the end of the year.

Opposition to a patent must be filed within nine months of the date the patent was granted, and Warcoin says they will wait until the 9 October deadline before filing to ensure their case is as strong as possible. Hockett says Myriad is unaware of the planned opposition, and would not comment until it had been filed.

The Curie Institute argues in particular that the requirement for samples to be sent to Myriad for testing will deny French scientists data and expertise, and will hamper development of new tests.

The opposition will also challenge the patent's breadth. As it covers all diagnostics based on the gene sequence, it allows Myriad to prevent the marketing of tests developed by the Curie Institute, and others, that use different techniques from Myriad's test.

Roger-Gérard Schwartzenberg, the French research minister, said last week that the government would introduce a bill to extend the laws that govern compulsory licensing to cover diagnostics, and consider exercising this power if Myriad refuses to license its tests to be carried out in France.

\title{
Helmholtz Society prepares itself for strategic reforms
}

\section{Quirin Schiermeier, Munich}

The Helmholtz Society, Germany's largest government-funded research organization, is expected to agree to sweeping reforms at its annual meeting in Berlin this week.

The reforms will introduce greater centralized control for the society's 16 research centres. The government proposed the changes earlier this year in an effort to increase the centres' relevance to industry and society, and to foster more collaboration and competition between the various sites.

The reform package will give the society's president and senate significantly more power to determine research goals and allocate funds, based on the result of scientific evaluations every five years.

But many Helmholtz researchers worry that this centralizing drive could undermine basic research and curtail their scientific independence.

Under the reforms, most of the organization's DM2.6-billion (\$US1.2-billion) annual budget will be earmarked to six strategic programmes. Researchers say that this will make it hard for them to get external grants from funding agencies, such as the European Commission, which expect host institutions to cover infrastructure and overhead costs.

In response to protests earlier this year,

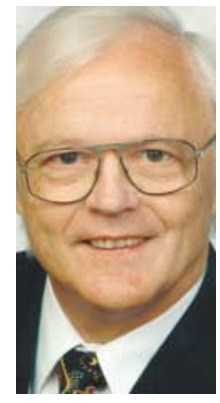

research minister Edelgard Bulmahn agreed to include "basic research" as one of the missions to be pursued by the society. "This is an important rider," says Rudi Balling, scientific director of the German Research Centre for Biotechnology in Braunschweig, "but only time will tell if it keeps our Walter Kröll: the scientific freedom alive." centres will keep their autonomy.

Walter Kröll, director of the German Space Agency, who is likely to be named in November as the Helmholtz's next president, defends the reforms. Research planning according to public demands "is not incompatible with scientific freedom", he says. "The centres will be left with enough autonomy to develop their own scientific profiles."

The first Helmholtz Society centres were set up in the 1950s to research atomic energy. Over the years, their activities have diversified and they now employ 8,000 researchers between them, and cover areas such as molecular genetics, cancer research, plasma and particle physics, space technology, and environmental, marine and polar research.

\section{Summit to put education at the heart of Brazil's future}

\section{Ricardo Bonalume, São Paulo}

A fresh focus for Brazilian science is likely to emerge from a summit to be held on 18-21 September in Brasilia.

Organized by the Ministry of Science and Technology, the National Conference of Science, Technology and Innovation will attempt to determine Brazil's science and technology policy for the next 10 years.

According to a 250-page green paper written to help guide the meeting, policy should move on from the traditional focus of research investment to tackle two areas of perceived weakness: general levels of public education and industrial innovation.

"The great success of the 'Asian tigers' came largely from the role that families give to the education of their children," says physicist Cylon Gonçalves da Silva, former director of Brazil's national synchrotron at Campinas, near São Paulo. But the level of schooling for the average Brazilian has grown only slowly - from four years to six - since 1981, he points out.

Da Silva coordinated the 400 scientists involved in writing the green paper and helped to plan the conference's programme. The summit will involve representatives of scientific societies, industry and agriculture — the first such meeting since 1985. In the intervening years, Brazil has invested heavily in training $\mathrm{PhDs}$ and research, and has sharply increased its share of publications in leading international journals.

But a government freeze on university hiring means that the country is struggling to employ its new graduates. Writing in Nature $(413,16$; 2001), for example, four Brazilian researchers warn that "a whole generation of young PhDs will be lost to research".

"The idea of the conference is a very good one," says Glaci Zancan, a biochemist at the Federal University of Paraná and president of the Brazilian Society for the Advancement of Science. He says that it should focus on how science can help to address inequity in Brazilian society.

The meeting will help to produce a white paper on policy. But Brazil will elect a new president next year, and some fear that the new administration may ignore the paper, unless the meeting reaches a strong consensus on what it should say.

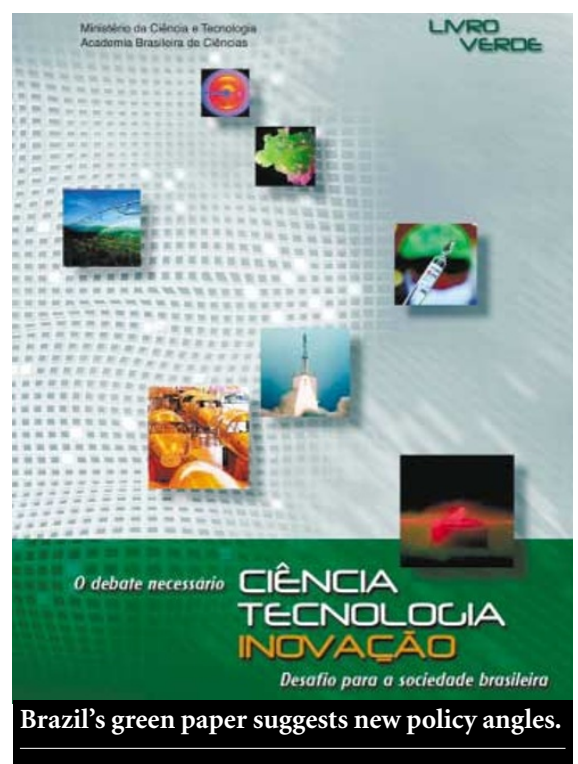

